\title{
Questes
}

\section{L'esplumoir virtuel : Chronicle of Highter Education et La Guilde des Doctorants}

Aimeric Vacher

\section{(2) OpenEdition}

1 Journals

\section{Édition électronique}

URL : https://journals.openedition.org/questes/4101

DOI : 10.4000/questes.4101

ISSN : 2109-9472

Éditeur

Les Amis de Questes

\section{Édition imprimée}

Date de publication : 15 janvier 2004

Pagination : $57-58$

ISSN : 2102-7188

\section{Référence électronique}

Aimeric Vacher, "L'esplumoir virtuel : Chronicle of Highter Education et La Guilde des Doctorants », Questes [En ligne], 6| 2004, mis en ligne le 01 janvier 2014, consulté le 23 août 2022. URL : http:// journals.openedition.org/questes/4101; DOI : https://doi.org/10.4000/questes.4101

Ce document a été généré automatiquement le 23 août 2022.

Tous droits réservés 


\section{L'esplumoir virtuel : Chronicle of Highter Education et La Guilde des Doctorants}

Aimeric Vacher

NOTE DE L'ÉDITEUR

Cet article n'a pas encore fait l'objet d'une autorisation de publication.

\section{ANNEXES}

The Chronicle of Higher Education

\section{INDEX}

Keywords : future, internet, recruiting, university

Mots-clés : futur, internet, recrutement, université 